\title{
The church as a catalyst for transformation in the society
}

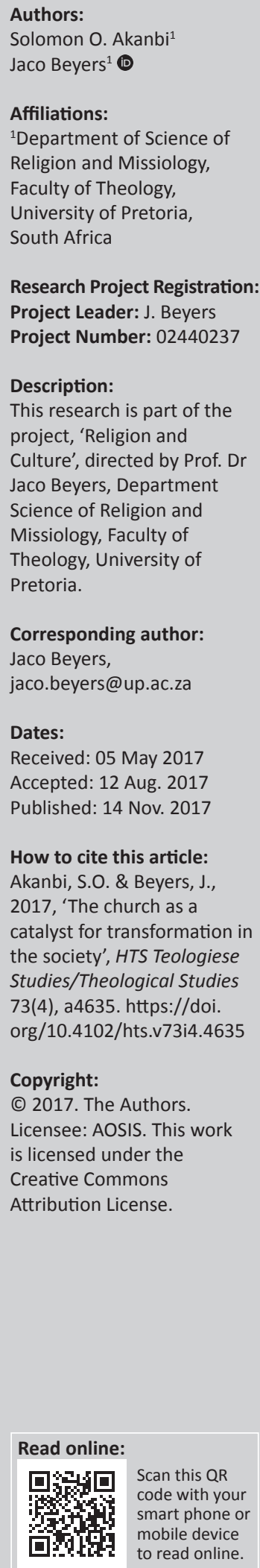

This article evaluates the activities of the church, especially the Pentecostal Movement in Nigeria, and their contribution to national development. It identifies the social, economic and political problems in Nigeria and discusses their interconnections and impacts on the development in Nigeria. It also identifies and analyses the approaches of the African Pentecostal Movement to socio-economic and political problems and evaluates the impact of these responses to the Nigerian society. Finally, it explores the role of the African Pentecostal churches in nation building and the transformation of the people of the south-western part of Nigeria. The church as a religious and social organisation, driven by moral and social principles as contained in the fundamental teachings and doctrine of Christian faith, is expected to play an important role towards the social change and the improvement on society's value system. This will lead to the transformation of the social life and put society in a holistic growth- and development-oriented direction. This article investigates and evaluates the assumption that Christianity is capable of influencing the society positively, using the Pentecostal movement as a case study. The article looks at the Pentecostals' contribution to social, political and economic lives of the people of the Nigerian society, especially the south-western part of Nigeria since the inception of the Pentecostal Movement in Nigeria. This article argues that Pentecostalism as a movement is fast growing and gaining attention from both Christians and non-Christians and has a major role to play in transforming the socio-political and economic lives of the people of south-western Nigeria. As such, this article offers a critique of the Pentecostal Movement using the Redeemed Christian Church of God, Deeper Life Bible Church and Living Faith Church as case studies.

\section{Introduction}

In Africa and indeed Nigeria, religion permeates all the activities from birth to death. In spite of this the Nigerian Constitution defines the country as a secular state. Three major religions predominate in the Nigerian society: Christianity, Islam and Traditional religion. The growth of Pentecostalism in most African countries has been phenomenal since 1967. However, since the 1980s, the new Christian movement has made a great impact on the Nigerian polity (Ndiokwere 1981:1-3). This was revealed in pages of the print media with incessant reports about the activities of the Pentecostal movements. Pentecostals also dominate the electronic media with their healing, preaching and miracle services, prosperity gospel and proclaiming itself through the use of tracts and literature, itinerant preaching, new ministries, Bible colleges, Sunday schools and also the use of the Internet.

In 2011, a Pew Forum study of global Christianity found that there were an estimated 279 million classical Pentecostals making $4 \%$ of the total world population. This represented $12.8 \%$ of the world's Christian Pentecostal population (Pew Research Centre 2011:67). Christianity makes up $56 \%$ of the population of Nigeria. According to Barrett and Johnson, Pentecostal denomination membership has been estimated to be at least a quarter of the world's two billion Christians (Barrett \& Johnson 2002:1). Vinson Synan, the Dean of the Regent University School of Divinity in Virginia Beach, told the triennial Pentecostal World Conference in Seoul in 1998 that about 25\% of the world's Christians are Pentecostal or charismatic (The Magazine 1998). Barrett in his statistics also submits that about 450 million are charismatic or Pentecostal. According to Pew Forum analysis carried out in 2011 on the Study of Global Christianity at Gordon-Conwell Theological Seminary, there are about 279 million Pentecostal Christians and 305 million charismatic Christians in the world. Observers differ on their analysis of the impact the Pentecostal movement is making on society. While some have commented that this movement largely has negative social, political and economic effects on the society, other commentators observe that Pentecostalism as

Note: This article is based on the research performed in preparation of a dissertation presented to comply with all the requirements for a PhD degree. The research was conducted under the supervision of Prof. Jaco Beyers of the University of Pretoria. 
a movement in Christianity has come at a right time to meet people's pressing economic, material and social needs and has empowered and encouraged people to participate in the community affairs and deliberation.

The origin of the Pentecostal movement in Nigeria can be traced to campus Christianity of the 1970s according to Ojo (2006:viii) through student prayer and Bible study groups such as inter-Varsity Christian Union. This was at a time of increase in higher education and national oil boom. The evangelical revival of the 1930s by Joseph Ayo Babalola with its African indigenous Christian spirituality and its emphasis on the efficacy of prayer and allowing its members to exercise the gifts of the Holy Spirit coupled with the influence of Western Pentecostal preachers like Oral Roberts through their print and media messages ushered in Pentecostalism in Nigeria. Although there is no direct link between the emergence of Pentecostal Movement in Nigeria to Azusa Street, nevertheless there had been linkages between leaders of the Nigerian movements and their Western counterpart. Therefore there is an interplay between both local and overseas initiatives to bring about what today is classified as the Nigerian Pentecostal movement. It was the entry of Pentecostalism into institutions of higher learning according to Ojo (ibid, xix) that triggered the spread of the movement in the country as educated youths with widened horizons of experience with their educational attainment promoted this new trend (Pentecostalism) in Nigerian Christianity.

The percentage of Pentecostals of the Christians in Nigeria is difficult to determine despite their unprecedented growth, because of many factors. First, the problem of typology of the movement as many churches claimed to be Pentecostal through deriving their church name from the term 'Pentecostal', while some claimed that all churches are Pentecostal. However, going by scholar's description of what constitutes a Pentecostal Church; churches that emphasise the power of the Holy Spirit, the manifestation of the gifts of the Spirit and speaking in tongues as evidence of being Born Again and efficacy of prayer are considered as Pentecostal Movement. Again, there are churches that fall within these descriptions that will not be ready to associate with the Pentecostals like some Indigenous African Initiated Churches. Second, statistical records in Nigeria as per Nigeria population are inadequate. For example the 2006 census puts the country's population at 140431790 million. The result of the 2006 census is of little relevance to this article because it did not enumerate religious affiliation. In the data published by the Nigeria Population Census and National Bureau of Statistics in 2016 the national population stands at 193392 517. The general consensus which is not backed by research data is that Muslims and Christians in Nigeria are about the same size which may be put at $45 \%$ each while others carry $10 \%$. If we go by this assumption and with the fact that Pentecostalism is growing at a higher rate in Nigeria based on my field research this author will put the Pentecostal population at about $20 \%$ out of the $45 \%$ of the Christian population in Nigeria with its figure at about 90 million out of about 194 million of the Nigerian population.
Pentecostals in Nigeria may be put at about 40 million. However, this figure may be contested because there are people who attend Pentecostal churches as their second church but also belong to the mainline churches or Independent African Churches as their first church. I will therefore submit that the best narrative on the Pentecostal statistics will be to record that the movement is growing rapidly attracting young and old, rich and poor with its population running to millions of adherents.

By the 1990s, the Nigerian Pentecostal Movement had also become a major factor in Nigerian public life. At the time, the middle class had been decimated by harsh economic realities as social, economic and political conditions in Nigeria which became worsened in the 1990s; millions of middle- and working-class Christians increasingly abandoned the mainline churches and joined Pentecostal churches that offered a 'prosperity' doctrine, welfare programme and instantaneous miracles to solve personal, social and financial problems. Anderson (2004:162), commenting on the reason for the expansion of the Pentecostal message in Africa in the 20th century, says it can be attributed, at least, partially, to cultural factors. For example, both Pentecostalism and Christianity in Africa utilise 'oral structures', which include an oral liturgy, narrative theology and witness, reconciliatory and participant community, the inclusion of visions and dreams in worship, and the understanding of the relationship between body and mind revealed in healing by prayer and liturgical dance. Furthermore, Hollenweger (1997:23) points out that spontaneity and enthusiasm in Pentecostal worship, rather than leading to an absence of liturgy, produce flexible oral liturgies memorised by the congregation. The most important element of these liturgies is the active participation of every member in the congregation.

By the beginning of the 21st century, Pentecostalism had become a major expression of Nigerian Christianity which may partly be because of the enthusiasm that goes with its services, the relative novelty of its message, increased media attention on its strategy and the proliferation of a large number of new churches and its pragmatic action towards alleviating the suffering of the masses. Some of them even advertise themselves widely in the printed and electronic media in a very competitive religious landscape. Scholars researching Pentecostalism have been commenting on the activities of the movement, especially as it relates to its engagement with the society and their activities as a catalyst for change.

\section{Assumptions on the capability of a religion like Christianity}

Religion is considered an important aspect of society, especially in Africa where people are deeply religious (compare Mbiti 1969:1). All the major faith traditions like Christianity and Islamic traditions have core principles that can motivate bonding and bridging social capital through community service, corporation, peace-making, pursuit of social justice and the possibility of respect and tolerance for 
others (Furbey \& Rowntree 2006:8). According to Nicholas Wade religion expresses a society's collective wisdom, past and present as to how its members should best behave in order to enhance the society's survival (Wade 2009:276).

The church played an important role in the politics of the later Roman Empire. The church preserved Western civilisation through the Dark ages and was in the forefront of European politics until the 17th century and beyond. According to Wade, it was when people turn to secular states and some premises and modern knowledge that religion was no longer appreciated (Wade 2009:276). Religion may not seem so essential in terms of security and prosperity when the social fabric appears reasonably robust. The test comes in times of crisis, whether warfare or economic disaster (ibid 278). Religion goes further and beyond its role in strengthening the social fabric. Religion exerts a cultural influence so deep that it has in effect become a defining factor of the world's major civilisations. Even in the most secular countries religion strongly influences the way people identify themselves (ibid).

As a religion, and social organisation, Christianity proposes that she is capable of transforming any society positively. According to O'Donnell (Sabet 1996) what Christianity offers is an interpretation of social reality. He continues that by the teaching of personal responsibility and accountability, the Church provides restraint to those under her influence. This assertion of $\mathrm{O}^{\prime}$ Donnell is true of what Christianity is able to offer but whether the adherents of Christianity allow these teachings to reflect in their lives is something that must be critically examined.

Furthermore, there is the assumption that if Christianity dominates a community and overrules the traditional laws, ethics and norms with her model principles of life, such community will be transparent in politics, policy formulation and implementation of public programmes and projects. In other words, in a community where there is a considerable influence of Christianity, there should be less of social vices because Christian teachings and doctrines are aimed at transforming individual lives, re-branding the society, such that there will be political stability, economic prosperity, social and moral sanity, a reduced rate of corruption and mutual cooperation among individuals and groups, including religions. This assumption is tested in this article. In addition, it is also assumed that if Christian principles and teachings are faithfully adopted and properly inculcated into the people, the societal value system will be fine-tuned such that the people's attitude to life will be positive and well informed towards an effective social transformation of a socially bankrupt society like Nigeria.

Similar to O'Donnell's position, Amr Sabet (1996:97) postulates that, irreligious institutions and structures fail to offer answers to newly emerging problems and instead confine their efforts to protecting and preserving their inherited privileges; the result will be either schism or the disenchantment of the masses (Sabet 1996:247). This school of thought, therefore, submits that religion can survive only if it perceives itself as functioning in a specific social context by which it is affected and which it attempts to shape or reconstruct. This article aligns with this position and holds that because religion cannot exist without the people and unless it is relevant to the people within a given society, it cannot stand the test of time. This assumption is tested in the course of this article because there are other scholars who differ but believe that Christianity introduced evils such as capitalism and individualism to society. Compare in this regard the introduction of the notion of capitalism by Max Weber ([1930] 2002:xi).

Emile Durkheim, stressing the importance of religion and its role, states that in the most primitive tribe, religion is a strong integrative force through its instillation of common values and identity and that religion comes with values and norms that are shared within groups. This, according to him, helps strengthen the integrity of a society (Durkheim 1997:130-131). Durkheim is interested in religion largely because he considers religion to be especially effective in developing common value and, therefore, it is a good source of integration (ibid).

The Social Capital theory grants a framework for understanding the influence of the Pentecostal movement on social capital. According to Putnam (2001), faith communities are the oldest community-based institutions that provide for social networks and support the influences on lifestyle. There are some prominent constructs that can be utilised for the analysis of Social Capital theory in a society. They are trust, reciprocity, networking and volunteerism. Trust, according to Smidt, is the lubricant that guarantees the efficiency of any group. It is produced when people believe that their group members act on their behalf and not against them (Smidt 2003:68).

Faith-based organisations, according to Putnam, are centred on social capital and civic engagement in the AfricanAmerican community (Putnam 2001:68). He states further that the church is the oldest and most resilient institution in Black-American communities, and those African Religious congregations are generally expected to serve their community and deal with the social needs of their community. Two features of religion contribute to the formation of social capital. Firstly, religion fosters group cohesion. Secondly, it has the ability to nurture and sustain reciprocity among actors. As Coleman points out 'churches provide our society with a more participatory, more egalitarian and more communitarian ethos that would be evident in our society without them' (Coleman 2003:36).

\section{The Nigerian society}

Nigeria is one of the most religious countries in Africa, considering the number of churches present in the country. According to experts like Aidelunuoghene (2014), up to $80 \%$ of the population live below the poverty line, and social services and infrastructure are limited. The country's poor rural women and men depend on agriculture for food and income. About $90 \%$ of Nigerian food is produced by small-scale farmers who 
cultivate small plots of land and depend on rainfall rather than irrigation systems. Nevertheless, over $56 \%$ of Nigerians are practising Christians, with the overwhelming majority of the Christians in Nigeria attending Pentecostal churches, especially in the south-western Nigeria, which this article is focussed upon. It is disheartening to experience the astronomical rate of social degradation and naked prevalence of other unprintable vices in the society. Efe Azino, analysing the proliferation of Churches in Nigeria, submits that almost every major street within the urban areas of Nigeria today plays host to a church. Millions of Nigerians, from the North to the South pledge allegiance to one Christian denomination or another, just as much as Church auditoriums and Crusades are thronged with millions of worshippers all across the nation. Yet, corruption remains rampant. The question automatically lends itself: how much influence does the Church bring to bear on Christian adherents and worshippers? To what extent does it, or has it been able to regulate the behaviour of millions of Nigerian Christians? And if this influence was effectively asserted, what would be its impact on checking corruption? (Azino n.d.) ${ }^{1}$

By the time Nigeria gained her independence in 1960, there were high hopes of sustainable development based on natural endowment. Regrettably, according to the Guardian Newspaper (March, 2009), these hopes were shattered when Nigeria began to experience an inexorable slide from a country with the most promising prospect in Africa to one that ranks among the least developed ... of the world'. However, because Nigerians are by nature inherently religious, the apparent dismal failure on the part of the government to arrest these unpalatable circumstances has resulted in the unprecedented growth of Pentecostalism. For the African, every occurrence, positive or negative, is given a spiritual undertone.

\section{Contribution of Nigerian churches to transformation of the society}

It is pertinent to understand the role that religion plays in social change and the activities of certain revolutionary movements. According to Oludele Ajani, religion remains one of the oldest, yet the most dynamic of social institutions. $\mathrm{He}$ argues that the assumption that religion in modern societies would gradually diminish in importance or become less capable of influencing public life is now becoming a matter of dispute and that Christian doctrine and practices could be earnest and integrated into the developmental process with a bid to enhancing the livelihood of Nigerian citizens (Ajani 2011).

Through their social interaction in the religious sphere, the Pentecostal movements have made their contributions to the well-being of the society. For example, the establishment of rehabilitation centres, hospitals, providing centres for youth empowerment programmes and so on.

1.Internet source - Article by Efe Azino, Proliferation of Churches and corruption in Nigeria: Understanding the Irony,http://www.academia.edu/6468351/Proliferation Nigeria: Understanding the Irony,http://www.academia.edu/6468351/Proliferation
of_Churches_and_Corruption_in_Nigeria_Understanding_the_Irony (viewed 24 March 2015)
The Pentecostal Movement, referred to in this article, is not generally conservative or fundamentalist in nature; it engages in some public and civic activities such as establishment of schools and hospitals for their members and non-members. They also established rehabilitation centres for the destitute and drug addicts within the society and many more, as considered in this research.

Rehabilitation programme: Some of the Pentecostal churches embark on a project entitled rescue, rehabilitation and reconciliation. The focus on rescue, rehabilitation and reconciliation reflects the emphasis on individual and social transformation in Nigerian Pentecostal spirituality. Pentecostal responses to street children are shaped by concepts of the family. While they acknowledge the importance of extended family structures, they believe that the nuclear family should take precedence. Thus, children who live outside their families, such as street children, are regarded as the deviant 'other' in need of rescue, rehabilitation and if possible restoration to their families of origin. In this regard, conversion is perceived as an essential 'ritual of rapture', enabling street children to make a clean break from their former lifestyles and addictions. What sets the Pentecostal initiatives apart from government and other civil society initiatives is their emphasis on spiritual formation, empowerment and equipping for ministry as evangelists to their former companions on the street. For example, God Bless Nigeria Church has a discipleship programme to socialise and empower new members recently 'rescued' from the streets. The programme culminates in a 'school of ministry' aimed at turning them into evangelists. Currently, its street ministry comprises mainly former street children who have gone through the discipleship programme. It is felt that their familiarity with street life enables them to reach out more effectively to those still living on the streets than other church members.

Pentecostal churches engage in establishing schools and other educational institutions and through the newly educated generations to bring about radical change in their value system and worldviews. The Christian contribution to the building of the Nigerian nation is best appreciated when we note that it is with the Christian missions in Nigeria that the institution of press and journalism began in this country. The God of the Bible and the Gospel proved efficient and vibrant agents of transformation that ensures the growth and vitality of the nation. Covenant University, Otta, Ogun State, was established by the Living Faith Church. Redeemers' University was established by the Redeemed Christian Church of God (RCCG). Many other Christian Universities are being proposed and in the pipeline. For instance, the Deeper Life Bible Church is proposing Anchor University to be sited in Abuja. Through these Christian-influenced tertiary institutions, a new generation has been as is still being instilled with Christian values, strengthening the moral fibre of society.

The key emerging features of Nigeria's new private universities involve ownership, enrolments and tuition levies. The ownership of private universities in Nigeria is dominated by religious organisations, especially the 
Pentecostal churches. The rising profile of indigenous Pentecostal churches that own private universities is noteworthy. These churches have a large membership and enormous wealth; they are concentrated in the south-west region of the country, which is where the majority of the private universities are located. Enrolments show significant potential for growth - at least based on evidence from one of the oldest new private universities; Madonna University, which graduated 390 students during its first convocation ceremony in 2004, had 7000 students as of 2005.

Currently setting the pace in some of their services and functions, private universities owned by most of the Pentecostal churches have become a challenge to their public counterparts. So far, they have continued to maintain stable academic calendars unlike the often-disrupted public universities. The new private universities have countered the effect of secret-cult groups present among students in public universities; the clashes, violence and killings involving these groups have become a regular feature for well over a decade now. The teaching and learning environment has generally been better in the private than in the public universities. With respect to standards, on average, the private universities have done much better in the National Universities Commissions accreditation process than their public counterparts. For example, in the commissions 2005 accreditation, none of the programmes evaluated in five private universities failed accreditation as did many of their public counterparts. In 2006 the accreditation panel again confirmed the higher rating of private universities in Nigeria. This shows some of the greatest contributions made by the private universities so far, as the emerging institutional competition would eventually help to restore the lost glory of higher education in Nigeria after the devastation wrought partly by the long period of military dictatorship. A private quality edge would also counter the more prevalent African situation in which the top universities continue to be located in the public sector. In the 2015 Nigerian University Commission (NUC) ranking three private Universities owned by the Living Faith Church and RCCG were ranked within the best 20 universities out of 100 top rated universities. Covenant University Ota owned by the Living Faith Church ranked fifth above any state university. Landmark University Omu-Aran also owned by the Living Faith Church ranked 12th and Redeemer University Ede owned by RCCG ranked 18th position. ${ }^{2}$

However, there are dissenting views that counter the above submission that most tertiary institutions established by Pentecostals are expensive with, criticising the Pentecostal institutions to be too expensive. Many Pentecostal churches have nurseries, primary and secondary schools, and even private universities. However, the programmes are being criticised as too expensive and beyond the reach of the common citizen. In fact, some people believe that it is a diversionary trend from the initial thought of the early missionaries. It is also observed that it is true that the establishment of private universities by some of the churches 2.http://nigerianscholars.com/2015/09/nucs-2015-list-of-top-universities-in-nigeriaranking.html would create employment and provide admission to the admission seekers. The question is: how many poor people in the church could afford to send their children to such schools they laboured to build as church members? It is being seen by some people as business enterprises in Nigeria. Some observers comment that it has become a rat race among the major Pentecostal preachers to establish schools like these.

Furthermore, another negative submission has to do with Pentecostals affecting the advancement of knowledge. According to Olusegun Fakoya:

If we have any hope of reclaiming the 'glory days' in Nigeria and leveraging our human resources in preparation for the competing and advancing in the 21st Century, our hopes are dashing before our eyes by Pentecostalism replacing curiosity for knowledge. When a sizable number of a nation's citizens relegate their everyday life circumstances to 'praying' rather thinking how to take care of that problem, that nation is in trouble. When pastors become the source of wisdom and 'knowledge platforms' relegated to religion, what could actually become of that nation? It's scary to see religion have such a stranglehold on the productive age of a young nation such as Nigeria, at the expense of natural knowledge pursuit. (Discussion on Religion and Spirituality 2008)

In particular, our citadels of learning, which embraced evangelism with exposure to the extremely materialistic American televangelists and crusaders like Benny Hinn, Oral Roberts and others, have started a suicidal journey to prehistoric existence at the expense of modern advances in science. It might be relevant to know that:

in the universities, for example, there is a growing pre-scientific outlook which accepts as reality the ideas and views, the legends and myths, usually associated with agricultural pastoral communities of prehistoric eras. Accordingly, biblical stories are now widely viewed as literally true, even though this tends to reduce aspects of evangelical Christianity to the level of the anthropologist's concept of primitive religion and magic. (Akinola 2006)

In our increasingly normless society, the educational system has practically collapsed and those who are being trained to propel the country forward are now relegating knowledge in the background on the platform of religion.

In the words of Ikeogu Oke (American University of Nigeria), modern-day Nigerian Pentecostalism has turned our youths into unthinking beings, so much so that they would rather pray about their grave existential problems resulting from bad leadership than seek active ways to tackle them headlong. The situation is so bad that today student protests against bad government are rare. The emphasis on prayers, as actively ingrained by the Pentecostal ministers, now supersedes active socio-political activism on the part of Nigerian students. This has led to an actively docile student populace, not even whimpering in the presence of social discontent and injustices. ${ }^{3}$

The welfare package of some Nigerian Pentecostal movements may be considered to have reduced poverty by

3.http://www.bc.edu/vc org/avp/Soe/cihe/newsletter/number45/p1406asi.htm 
providing and promoting education and training for the social and economic welfare of women. The women have adopted methods to alleviate poverty among members. One of these projects is embarking on joint economic ventures, which enable church branches to carry out income-generating projects. Profits from the projects are used to assist the members who are in difficulties and to carry out charitable work among the poor and needy of the society. At the annual Easter and December retreats of the Deeper Life Bible Church the participants were given 'free food and lodging'. Some years later, free transport was also added. In 1997 the Living Faith World Outreach provided food, clothing and other relief materials to indigenes of Korna Hills in Adamawa State, where natives had long been disconnected from civilisation. A year before that, the church gave relief materials to victims of the Liberian Civil War. It has been argued elsewhere that providing such palliatives may not solve the poverty being experienced in the Nigerian society and elsewhere.

Some Pentecostal churches had been involved in the rehabilitation of drug addicts and some other people who are homeless within the society. Having examined some of the contributions of the Pentecostal churches to national development, it is, however, imperative to consider their activities critically because the Gospel of Jesus Christ is being given a new interpretation daily. For example, through personal evangelism the Pentecostal churches have been able to come across drug addicts and preach to them repentance and after repentance, they rehabilitate these group of people in the society.

Social concern of members in the form of pastoral care is considered as progressiveness of the Pentecostal Movement which has, in turn, contributed to another factor that contributes to the flourishing of Pentecostal churches. Pentecostal pastors are considered by some observers as exceptionally good in pastoral care. The moment a convert enters their churches, they are handed over to a team of follow-up specialists who give personal attention and care to new converts. Within a short while, the new convert feels totally reassured as his past, present and future experiences are revealed by the man or woman of God. He is told what to do to have a better social condition. The progressiveness in Pentecostal churches is also seen in the readiness of the prophets or pastors to spend a lot of time with each sick person. Most of the Pentecostal churches have a specific member called a worker, evangelist or elder whose duty is to visit and admonish new members of the church.

The traditional Pentecostal position had been to decry medical healing and to prioritise divine healing. Kay reveals that the intensity of the 'faith' position was associated with less well-educated older Pentecostal ministries, although few groups of younger ministries also took this position (2000:283). However, some Pentecostal churches establish hospitals and medical care centres, charging affordable fees to assist the poor and the less-privileged. These hospitals are built by religious bodies to supplement and challenge inadequacies of the government health care system. Examples are the Baptist Hospital Ogbomoso, Wesley Guild Hospital,
Ilesa, the Sacred Heart hospital of the Society of African Missions in Abeokuta, Seventh Day Adventist Hospital, Ile Ife and Saint Luke Medical Centre in Ibadan. Building and administering hospitals do not differentiate churches from other secular entities doing the same. The values and principles applied in administering hospitals can however be derived from a Christian background. This differentiates such hospitals from secular entities.

Religious bodies are also visible stakeholders in banking, insurance and other sectors of the Nigerian economy. For instance the ownership of the Haggai Bank and New Life Zion Community Bank are linked to RCCG and is located at the Redemption camp of the RCCG.

The Pentecostal churches have also contributed immensely to the development of media and internet facilities in Nigeria, especially during the 20th and 21st centuries. The publication of tracts, magazines, novels and writings in national dailies is a regular feature. The majority of the Christian literature publications are published by the Pentecostal Church leaders. The radio and television method of communication is a common phenomenon today. Some of the Pentecostal pastors have regular and appointed times to preach the gospel on the radio and television at the federal, state and private stations. Programmes on Radio include devotional services, which involve only morning and evening prayers mostly on government stations, Sunday worship services, jingles and announcement of revival meetings and church programmes, full-length preaching or teaching programmes and occasional interviews granted to church ministers. There are about 10 radio stations in Lagos alone, broadcasting close to 60 fulllength religious programmes per week, ranging from 15 to 55 minutes in length.

Pentecostal churches also have scholarship programmes for indigent students. Oyedepo once said: 'All school age children not in school due to the inability of parents will be fully taken care of by the church' (The News Magazine 2009:21). In this way the church contributes to the education and training of individuals who can because of education earn an income and contribute to the transformation of society at large.

\section{Evaluation}

It is necessary to look at the critique of the Church, especially the Pentecostal movement. Some scholars commenting on the vitality of Pentecostalism argue that the Pentecostal movement is the most important mass religious movement of the 20th century. Among scholars with this submission is Grant Wacker who postulates that Pentecostalism's inauspicious beginning at the turn of the century makes the movement's growth even more surprising. Allan Anderson in his book An Introduction to Pentecostalism (Anderson 2004:162) states that Pentecostals and the Spirit churches undoubtedly have played a part in the emergence of new religious groups in Africa. This submission is corroborated by groups that emerged through the influence of Western Pentecostalism in Nigeria like Scripture Union, Student 
Christian Movement, which later became part of the catalyst for the emergence of Nigerian Pentecostalism.

Paul Gifford (1988), in his study on Ghana's New Christianity, argues that the movement does not engage adequately in attacking structural injustice, while others have distinguished covert from overt political engagement. Intercession could be a form of political praxis, but the data differ from region to region, and from country to country. Yet, there is the contradictory image that Pentecostalism empowers people to engage the modern economic space and technologies, to operate with optimism that God is with them in the market place, and to reject defeat from economic failures of the nation. It seeks the freedom to baptise all nationals with the gospel in obedience to the Great Commission. David Martin in his book on Pentecostalism, The World Their Parish, states that evangelism has remained at the core of the movement from its inception. Indeed, the emphasis on tongues was an aid to mission (Martins 2002:10).

More than 30 years ago, Anglican Bishop John V. Taylor, as quoted by Anderson, stated:

I believe the time has arrived when we must take into account all that is positive in the Pentecostal movement, if we hope to press further forward along any of the various roads of liturgical renewal, inter-faith dialogue, the indigenisation of Christianity, experiments in Christian community and group experience, the ministry of healing, especially towards psychotics and addicts, and new approaches to church union. (2004:162)

This submission is crediting the importance of the movement cutting across socio-religious aspects of human engagement.

In Nigeria, religion appears to be the most lucrative business today which has informed multiplication of churches, especially new generational churches. One may be tempted to agree with Weber (2002[1930]:xi) that there seems to be an inalienable casual connection between moneymaking and religious enterprise today. This is largely because of the promotion of prosperity gospel, sweeping through Africa, especially Nigeria. Prosperity Gospel runs contrary to the fundamental teachings of Christian religion which is detachment from material possession and seeking for heavenly realities, i.e. earthly realities are not ends in themselves; rather they are means to an end. Prosperity Gospel is an aberrant theology from the traditional interpretation of the Bible. This was corroborated by Dominic Umoh (2013) in the African Journal of Scientific Research.

\section{Conclusion}

Churches and all faith institution in a religious society like Africa, in particular, are expected to play a very important role in motivating and influencing the social-political and economic life of the people within their community. As has been stated in the beginning of this article, religion goes further and beyond its role in strengthening the social fabric. Religion exerts a cultural influence so deep that it has in effect become a defining factor of the world's major civilisations. Despite the shortcomings of some of the Pentecostal churches, especially in their emphasis on health and wealth gospel, their contribution to nation building cannot be overlooked as their contribution is significantly remarkable, bridging the gap where the government of the day is lacking behind, especially in the area of qualitative education. In this way religion, Pentecostalism in particular, does influence society. However, the Church, especially the Pentecostal movement can do better with the resources available to the Church because they influence the majority of the highly placed young Nigerian working class. Pentecostals can do better to fulfil the Great Commission which should not be limited to preaching alone but aiming at the converting and influencing the totality of a common human. The bad leadership and bad governance which have resulted in the socio-political and economic backwardness of the nation paved way for the recognition of the Pentecostal movement by most young Nigerians as the saviour of the moment. Pentecostalism has the ability and has created the infrastructure (i.e. hospitals, schools and universities) to instil values and principles guiding a generation to overcome their social problems and live life to its fullest. Therefore, there is no doubt that the churches in this category have contributed immensely to the religious, political and socio-economic development of the country.

\section{Acknowledgements Competing interests}

The authors declare that they have no financial or personal relationships which may have inappropriately influenced them in writing this article.

\section{Authors' contributions}

This article is based on the research performed by S.O.A. in preparation of a dissertation presented to comply with all the requirements for a $\mathrm{PhD}$ degree. The research was conducted under the supervision of J.B.

\section{References}

Aidelunuoghene, O.S., 2014, 'The Paradox of poverty in Nigeria: What an irony', Research Journal of Finance and Accounting 5(4).

Ajani, O., 2011, 'Sociological analysis of religion and community in South Western Nigeria', Ife Social Sciences Review 24(1), 77-89.

Akinola, G.A., Religion and Obasanjo Administration, viewed 20 April 2016, from https://www.laits.utexas.edu/africa/ads/1543.html

Anderson, A., 2004a, An introduction to Pentecostalism: Global Charismatic Christianity, Cambridge University Press, Cambridge.

Anderson, A., 2004b, 'Pentecostalism, healing and ecumenism', Academic Journal Article - International Review of Mission 3(1).

Azino, E., n.d., Proliferation of Churches and corruption in Nigeria: Understanding the irony, viewed 24 March 2015, from http://www.academia.edu/6468351/ Proliferation_of_Churches_and_Corruption_in_Nigeria_Understanding_the Irony

Barrett, D.B. \& Johnson, T.M., 2002, 'Annual statistical table on global mission: 2002', International Bulletin of Missionary Research 26, 1. https://doi.org/10.1177/ 239693930202600106

Coleman, J.S., 2003, Social capital in the creation of human capital, Oxford University Press, Oxford.

Durkheim, E., 1997, The Division of Labour in Society, The Free Press, New York.

Fakoya, O., 2008, 'Discussion on religion and spirituality', The Gospel of Materialism - Nigerian Pentecostalism and Hypocrisy Nigeria World, viewed 14 October 2015, from www.saharareports.com/2008/09/26/gospel-materialism---nigerianpentecostalism-and-hypocrisy 
Furbey, R. \& Rowntree, F.J., 2006, Faith as social capital: Connecting or dividing? Bristol Policy Press, Bristol.

Gifford, P., 1988, African Christianity: Its public role, Hurst \& Co, London.

Hollenweger, J.W., 1997, Pentecostalism: Origins and developments worldwide, Hendrickson Publishers, Peabody, MA.

Kay, W., 2000, Pentecostals in Britain, Paternoster Publishing, Carlisle.

Martins, D., 2002, Pentecostalism: The World Their Parish, Blackwell Publishers Ltd., Oxford. Mbiti, J.S., 1969. African religions and philosophy, Heinemann, London.

Ndiokwere, N., 1981, Prophecy and revolution: The role of prophets in the independent African churches and Biblical tradition, Camelot Press Ltd., Southampton.

Ojo, M., 2006, The end-time Army: Charismatic movements in modern Nigeria, Africa World Press, Trenton.

Pew Research Centre for the People \& the Press and Pew Forum on Religion \& Public Life, 2011, Global Christianity - A Report on the Size and Distribution of the World's Christian Population, Washington, DC, Dec 2011, viewed 14 Oct. 2015, from http://www. population, Washington, DC, Dec 2011, viewed 14
pewforum.org/2011/12/19/global-christianity.exec/
Putnam, R.D., 2001, Bowling alone; The Collapse and revival of American community, Simon and Schuster, New York.

Sabet, A., 1996, 'Religion, politics and social change: A theoretical framework', Religion, State \& Society 24(2/3), 247.

Smidt, C., (ed.), 2003, Religion as social capital: Producing the common good, Baylor University Press, Waco, TX.

The Magazine, 1998, viewed 16 November 1998, from http://www.Christianitytoday com

The News Magazine, 2009, 'Inside Nigeria churches, the good and the bad', The News Magazine 33(24), 21.

Umoh, D., 2013, 'Prosperity Gospel and Spirit of Capitalism: The Nigerian Story', African Journal of Scientific Research 12(1), 657, 34

Wade, N., 2009, The faith instinct: How religion evolved and why it endures, Penguin Press, New York.

Weber, M., 2002[1930], The protestant ethic and the spirit of capitalism, Routledge Classics, New York. 